\title{
PENERAPAN MODEL PROBLEM BASED LEARNING DALAM MENINGKATKAN HASIL BELAJAR SISWA
}

\author{
Reni Widiyawati \\ Program Studi Pendidikan Sejarah FKIP Universitas Lambung Mangkurat \\ Banjarmasin
}

Email: reniwidiyawatinyai@gmail.com

\begin{abstract}
Abstrak: Inovasi didalam dunia pendidikan sangatlah diperlukan, karena dengan adanya inovasi tersebut dapat meningkatkan hasil belajar yang maksimal. Selain perlunya inovasi dalam dunia pendidikan, guru yang profesional juga sangatlah berperan penting, karena dengan adanya guru yang profesional akan menumbuhkan dan menciptakan generasi-generasi yang berbakat dan seorang guru akan mempengaruhi bagaimana cara pandang para peserta didik dalam memaknai dan memahami suatu pembelajaran. Maka dari itu didalam suatu pembelajaran sangat diperlukannya strategi pembelajaran seperti model-model pembelajaran, metode pembelajaran, media pembelajaran dan cara mengaplikasikan pembelajaran yang dapat membantu seorang guru dalam mempermudah proses pembelajaran, agar pembelajaran itu berjalan secara baik dan dapat menumbuhkan kesan yang baik pula didalam diri peserta didik. Dengan adanya model-model pembelajaran itu diharapkan dapat menumbuhkan rasa kecintaan peserta didik dalam belajar dan meningkatkan hasil belajar mereka.

Model pembelajaran Problem Based Learning adalah suatu model yang sangat baik untuk diterapkan atau digunakan seorang guru dalam proses pembelajaran. Karena dengan menggunakan model problem based learning ini para peserta didik diajak untuk berpikir dan menuangkan pemikirannya sendiri. Maka dari itulah para peserta didik akan mempunyai pemikiran yang kritis.
\end{abstract}

Kata kunci: Problem Based Learning, Hasil Belajar

\section{PENDAHULUAN}

Dikutip dari Melisa Prawitasari (2015: 146) dalam dunia pendidikan guru memiliki peran penting dalam proses pembelajaran. Kemampuan guru dalam melaksanakan kegiatan belajar mengajar merupakan faktor penting untuk mencapai tujuan pendidikan. Secara umum guru bertugas mengembangkan kemampuan siswa secara optimal dalam aspek kognitif, afektif, dan psikomotorik. Dalam 
menjalankan tugas dan tanggung jawabnya, seorang guru perlu menjadi pribadi yang mulia, memiliki sikap yang membuat para siswa merasa nyaman dengan memberikan pengajaran dengan untaian kata-kata sarat yang bermakna mendidik.

Dikutip dari Lismaya (2019: 3) Pembelajaran merupakan suatu proses yang kompleks, karena dalam kegiatan pembelajaran senantiasa mengintegrasikan berbagai komponen dan kegiatan, yaitu siswa dengan lingkungan belajar untuk diperolehnya perubahan perilaku (hasil belajar) sesuai dengan tujuan (kompetensi) yang diharapkan (Rusman, 2011). Syaiful Sagala (2009: 28) menyatakan bahwa pembelajaran adalah proses komunikasi yang dilakukan secara dua arah antara pengajar dan pembelajar. Dalam proses tersebut, guru sebagai pengajar tidak hanya semata-mata memberikan informasi, namun juga menjadi fasilitator bagi pembelajar dalam mempelajari sesuatu kemampuan dan/atau nilai baru (Susanto, \& Akmal, 2019: 25).

Dikutip dari tulisan Susanto (2015: 34) Pembelajaran adalah dampak dari berpikir. Resensi, pemahaman, dan penggunaan aktif pengetahuan bisa tercipta hanya dengan pengalaman pembelajaran dimana murid berpikir tentang, dan berpikir dengan, apa yang mereka pelajari. Cara penerapan suatu pembelajaran akan berpengaruh besar terhadap kemampuan siswa dalam mendidik diri mereka sendiri. Penggunaan model pembelajaran yang tepat dapat mendorong tumbuhnya rasa senang siswa terhadap pelajaran, menumbuhkan dan meningkatkan motivasi dalam mengerjakan tugas, memberikan kemudahan bagi siswa untuk memahami pelajaran sehingga memungkinkan siswa mencapai hasil belajar yang lebih baik (Lismaya, 2019: 4).

Dalam proses pembelajaran juga diperlukannya sebuah media yang dianggap mampu untuk memperlancar sebuah proses pembelajaran yang dilakukan oleh seorang guru. Oemar Hamalik (1982: 23) menjelaskan bahwa yang dimaksud dengan media pendidikan adalah metode, alat dan teknik yang dipakai guna lebih mengefektifkan komunikasi, interaksi antara murid dan guru dalam proses belajar mengajar di sekolah. Media atau sering disebut pula dengan alat perantara merupakan dasar yang bersifat melengkapi dan banyak memberikan kelancaran dalam proses belajar mengajar dan berhasilnya pendidikan (Susanto \& Akmal, 2019: 15). Selain diperlukannya media dalam suatu proses pembelajaran, aplikasi juga sangatlah berperan penting dalam proses pembelajaran.

Dalam Jurnal Susanto, \& Akmal (2018) mengatakan bahwa aplikasi pembelajaran merupakan terobosan baru media belajar yang memberikan kebebasan mutlak bagi siswa mengoperasikannya. Pada dasarnya aplikasi pembelajaran memiliki manfaat untuk memudahkan siswa dalam mempelajari materi tertentu. Pemahaman merupakan proses yang dilalui seorang individu untuk 
menjadikan suatu pengetahuan menjadi milik dirinya dan pada akhirnya akan mempengaruhi proses berfikir dan bertindak individu tersebut. Menurut Suharsimi Arikunto (2003:17) pemahaman (comprehension) mempunyai arti mempertahankan, membedakan, menduga (estimates), menerangkan, memperluas, menyimpulkan, menggeneralisir, memberikan contoh, menulis kembali, memperkirakan (Susanto, 2014: 6-7).

Didalam dunia pendidikan tentunya kita sudah tidak asing lagi dengan yang namanya model-model pembelajaran yang dianggap mampu meningkatkan motivasi belajar para peserta didik yang tentunya juga dengan adanya model-model pembelajaran diharapkan mampu meningkatkan hasil belajar siswa. Permasalahan yang belum bisa diatasi sampai saat ini terutama didalam bidang pendidikan ialah kurangnya kemampuan guru dalam meningkatkan hasil belajar para siswa, faktor itu disebabkan oleh ketidaktahuan seorang guru dengan model-model pembelajaran yang mampu meningkatkan hasil belajar siswa. Maka dari itu, sangat diharapkan seorang guru mengetahui model-model pembelajaran dan mengaplikasikannya dengan baik dan benar agar dapat membangunkan rasa kecintaannya pada pembelajaran tersebut.

Dengan model pembelajaran Problem Based Learning sangat diharapkan mampu meningkatkan hasil belajar siswa pada pembelajaran sejarah. Karena dengan model pembelajaran ini siswa dapat berpikir secara kritis dalam memecahkan sebuah masalah dan para siswa diberikan permasalahanpermasalahan yang ada disekitarnya, dengan itu mereka tidak terlalu bingung dengan permasalahan tersebut karena permasalahan yang harus mereka pecahkan sangat dekat dengan kehidupan nyata mereka.

\section{MODEL PROBLEM BASED LEARNING}

Sebagai salah satu model pembelajaran yang menarik, banyak ahli yang membahas dan mendefinisikan model problem-based learning (PBL). Menurut Arends Problem-Based Learning adalah sebuah model pembelajaran yang berorientasi untuk memecahkan masalah. PBL sebagai model pembelajaran berusaha menyuguhkan berbagai situasi bermasalah yang autentik dan bermakna kepada siswa, yang dapat difungsikan dalam melakukan penyelidikan. Dalam proses PBL, dilakukan secara kolaboratif, sebagaimana mereka bekerja secara individu. Sementara Barrow (dalam Smith dkk, 2005) menjelaskan enam ciri khusus dari PBL, yaitu: (1) pembelajaran berpusat pada siswa, (2) pembelajaran terjadi pada kelompok kecil siswa, (3) guru berperan sebagai fasilitator, (4) masalah merupakan fokus dan stimulus dalam pembelajaran, (5) masalah merupakan jalan untuk pengembangan kemampuan pemecahan masalah secara klinis, dan (6) 
informasi baru diperoleh melalui pembelajaran yang mengarahkan diri (Muniroh, 2015: 37-38).

Menurut Trianto (2011), PBL mempunyai implikasi sebagai berikut. (1) mendorong kerjasama dalam menyelesaikan tugas. (2) mendorong peserta didik untuk melakukan pengamatan. (3) PBL melibatkan peserta didik dalam penyelidikan yang dipilihnya sendiri, yang memungkinkan mereka dapat menginterpretasikan dan menjelaskan berbagai fenomena dunia nyata serta bermanfaat untuk mengkontruksi pemahaman peserta didik terhadap fenomena tersebut (Simatupang \& Purnama, 2019: 10).

Dikutip dari tulisan Nafiah, \& Suyanto hal. 127 Menurut Glazer (2001) menyatakan bahwa PBL menekankan belajar sebagai proses yang melibatkan pemecahan masalah dan berpikir kritis dalam konteks yang sebenarnya. Glazer selanjutnya mengemukakan bahwa PBL memberikan kesempatan kepada siswa untuk mempelajari hal lebih luas yang berfokus pada mempersiapkan siswa untuk menjadi warga negara yang aktif dan bertanggung jawab. Melalui PBL siswa memperoleh pengalaman dalam menangani masalah-masalah yang realistis, dan menekankan pada penggunaan komunikasi, kerjasama, dan sumber-sumber yang ada untuk merumuskan ide dan mengembangkan keterampilan penalaran. Dikutip dari tulisan Rerung, N. dkk. Hal. 49 pembelajaran berbasis masalah atau problem based learning (PBL) adalah salah satu model pembelajaran inovatif yang memberikan kondisi belajar aktif kepada peserta didik (Nisa, 2015: 3).

Pembelajaran dengan menerapkan model PBL akan memberikan tantangan bagi peserta didik untuk mencari solusi dari permasalahan dunia nyata secara individu maupun kelompok. Pembelajaran dengan model PBL didasarkan pada prinsip bahwa maslaah dapat digunakan sebagai titik awal untuk mendapatkan ilmu baru. Masalah yang disajikan dalam pembelajaran diharapkan dapat meningkatkan motivasi peserta didik dalam memhamai konsep yang diberikan (Yusri, A. Y., 2018). Sedangkan menurut Saragih, dkk (2016) Problem based learning (PBL) adalah model pembelajaran yang potensial mengarahkan peserta didik memecahkan maslaah. Teori belajar yang mendasari PBL adalah teori penemuan yang mengarahkan peserta didik mmebentuk pengetahuan secara aktif (Simatupang \& Purnama, 2019: 9).

Pembelajaran berbasis masalah adalah suatu model pembelajaran yang menekankan partisipasi aktif dari mahasiswa, menumbuhkan keterampilan pemecahan masalah dan kemampuan berpikir kritis. Hal ini juga mendorong para mahasiswa didalam mengidentifikasi pengetahuan dan keterampilan mereka sendiri. Model problem based learning merupakan pembelajaran dimana masalah digunakan untuk menstimulus kemampuan berpikir mahasiswa. PBL adalah 
lingkungan belajar yang didalamnya menggunakan masalah untuk belajar, yaitu sebelum pembelajar mempelajari suatu hal, mereka diharuskan mengidentifikasi suatu masalah, baik yang dihadapi secara nyata maupun telaah kasus (Huriah, 2018: 9-10).

Model problem based learning (PBL) didasarkan pada kajian seorang filsuf pendidikan yaitu John Dewey, dia menekankan pentingnya pembelajaran melalui pengalaman (Jacobsen, Eggen, dan Kauchak, 2009: 242). Problem based learning (PBL) adalah pendekatan pembelajaran berstruktur instruksi organisasi secara bebas pada siswa dengan beberapa disiplin pengetahuan dan kemampuan (Borich, 1996: 306). Esensi problem based learning (PBL) berupa penyuluhan berbagai situasi bermasalah yang autentik dan bermakna kepada siswa yang dapat berfungsi sebagai batu loncatan untuk investigasi dan penyelidikan (Fahrurrozi, \& Hamdi, S. 2017: 66). Dikutip dari tulisan Setyorini, Sukiswo, \& Subali, 2011 hal. 55 Penggunaan model PBL dalam proses pembelajaran menjadi lebih aktif dan menyenangkan bagi siswa karena siswa lebih mengerti tentang hal-hal yang sering dialaminya dalam kehidupan sehari-hari. Dengan demikian, aktivitas ilmiah siswa dalam proses pembelajaran akan berpengaruh pada pertumbuhan aspek psikomotoriknya.

Model pembelajaran PBL memiliki kelebihan dan kekurangan. Menurut Sanjaya, W. (2012) terdapat beberapa kelebihan model pembelajaran PBL adalah: (a) teknik/cara yang cukup bagus untuk lebih memahami isi pelajaran; (b) dapat menantang kemampuan peserta didik serta memberikan kepuasan untuk menemukan pengetahuan baru bagi peserta didik; (c) dapat meningkatkan aktivitas pembelajaran peserta didik; (d) dapat membantu peserta didik bagaimana mentransfer pengetahuan mereka memahami masalah dalam kehidupan nyata; (e) dapat membantu peserta didik untuk mengembangkan pengetahuan barunya dan bertanggung jawab dalam pembelajaran yang mereka lakukan. Disamping itu, pemecahan masalah juga dapat untuk mendorong melakukan evaluasi sendiri baik terhadap hasil maupun proses belajarnya; (f) memperlihatkan kepada peserta didik bahwa setiap mata pelajaran (matematika, IPA, sejarah, dan lain sebagainya), pada dasarnya cara berpikir, dan sesuatu yang harus dimengerti oleh peserta didik, bukan hanya sekedar belajar dari guru atau buku-buku saja; (g) dianggap lebih menyenangkan dan disukai peserta didik; (h) dapat mengembangkan kemampuan peserta didik untuk berpikir kritis dan mengembangkan kemampuan mereka untuk menyesuaikan dengan pengetahuan baru; (i) dapat memberikan kesempatan pada peserta didik untuk mengaplikasikan pengetahuan yang mereka miliki dalam dunia nyata; (j) dapat mengembangkan minat peserta didik untuk secara terus menerus belajar sekalipun belajar pada pendidikan formal telah berakhir. (Simatupang \& Purnama, 2019: 11) 
Selain kelebihan tersebut pembelajaran PBL juga memiliki beberapa kekurangan. Menurut Sanjaya, W. (2012), pembelajaran berbasis masalah juga memiliki beberapa kekurangan antara lain: (a) manakala peserta didik tidak memiliki minat atau tidak mempunyai kepercayaan bahwa masalah yang dipelajari sulit untuk dipecahkan, maka mereka akan merasa enggan untuk mencoba; (b) keberhasilan strategi pembelajaran melalui pemecahan masalah membutuhkan cukup waktu untuk persiapan; (c) tanpa pemahaman mengapa mereka berusaha untuk memecahkan masalah yang sedang dipelajari, maka mereka tidak akan belajar apa yang mereka ingin pelajari (Simatupang \& Purnama, 2019: 12).

Teori dari strategi Problem Based Learning adalah teori belajar kontruktivistik (kontruktivisme). Pengertian kontruktivistik adalah belajar merupakan suatu proses secara aktif oleh peserta didik untuk membangun pengetahuan dan pemahaman. PBL menggunakan konsep-konsep belajar dari teori kontruktivistik sebagai landasan pengembangan PBL sendiri. Problem based learning (PBL) dikembangkan secara bersamaan dengan munculnya teori humanistik, maka dari itulah teori humanistik digunakan sebagai dasar dari teori strategi PBL. Pengertian dari teori humanistik ialah belajar dianggap sebagai perolehan informasi, pengalaman dan menemukan makna secara pribadi.

\section{HASIL BELAJAR}

Dikutip dari tulisan Khotimah, K. dan Wardani, D.K. 2020 hal. 30 hasil belajar merupakan perubahan perilaku yang diperoleh siswa setelah mengalami aktivitas belajar. Perolehan aspek-aspek perubahan perilaku bergantung pada apa yang dipelajari oleh siswa. Oleh karena itu, apabila siswa mempelajari pengetahuan tentang konsep. Dalam pembelajaran, perubahan perilaku yang harus dicapai oleh siswa setelah melaksanakan aktivitas belajar dirumuskan dalam tujuan pembelajaran.

Hasil belajar merupakan bagian terpenting berubahnya tingkah laku. Seperti yang dikemukakan oleh Sudjana (2009) bahwa hasil belajar siswa pada hakikatknya adalah perubahan tingkah laku sebagai hasil belajar dalam pengertian yang lebih luas mencakup bidang kognitif, afektif, dan psikomotor. Seperti yang dikemukakan oleh Arikunto (2001) bahwa hasil belajar adalah sebagai hasil yang telah dicapai seseorang setelah mengalami proses belajar dengan terlebih dahulu mengadakan evaluasi dari proses belajar yang dilakukan memuaskan (Syahputra, 2020: 24-25).

Hasil belajar merupakan prestasi yang dicapai setelah siswa menyelesaikan sejumlah materi pelajaran. Prestasi belajar merupakan hasil belajar yang ideal meliputi segenap ranah psikologis yang berubah sebagai akibat pengalaman dan proses belajar siswa (Sinar, 2018: 20-21). Hamalik (2013: 30) menyatakan bahwa hasil belajar akan tampak pada setiap perubahan pada aspek-aspek: pengetahuan, 
pengertian, kebiasaan, keterampilan, apresiasi, emosional, hubungan sosial, jasmani, etis atau budi pekerti, dan sikap (Mirdanda, 2018: 33).

\section{PENUTUP}

Model pembelajaran Problem Based Learning (PBL) merupakan sebuah pembelajaran yang melibatkan para peserta didik secara langsung didalam suatu proses pelajaran yang memerlukan praktek. Model pembelajaran PBL adalah model pembelajaran yang melibatkan siswa dengan permasalahan yang nyata sesuai dengan minat dan perhatian siswa tersebut. Sehingga dengan adanya model pembelajaran problem based learning ini menumbuhkan dan meningkatkan motivasi belajar dan rasa ingin tahu yang baik. Dengan itu diharapkan siswa mampu mengembangkan cara berpikir secara kritis dan memiliki keterampilan yang baik. Model pembelajaran ini juga memberdayakan daya fikir, kreativias dan partisipasi para siswa didalam sebuah pembelajaran. Model pembelajaran Problem Based Learning menerapkan sebuah pembelajaran yang tidak hanya terfokus pada guru saja. Tetapi para peserta didik juga diajak untuk berpikir secara kritis dan logis agar tercapai suatu pemikiran yang baik. Dengan model pembelajaran problem based learning ini guru memberikan masalah kepada peserta didik yang kemudian para peserta didik disuruh untuk berpikir dan memecahkan suatu permasalah tersebut.

Dengan digunakannya model pembelajaran problem based learning ini sangat diharapkan mampu menumbuhkan motivasi belajar para peserta didik dan menumbuhkan rasa penasaran dalam memecahkan suatu masalah. Dengan itu para peserta didik akan memiliki peningkatan dalam hasil belajarnya. 


\section{DAFTAR PUSTAKA}

\section{A. Buku:}

Fahrurrozi, \& Hamdi, S., (2017). metode pembelajaran matematika, NTB. Universitas hamzanwadi press

Huriah, T. (2018). Metode Student Center Learning. Jakarta: Prenadamedia Group

Lismaya, L. (2019). Berpikir Kritis \& PBL (Problem Based Learning. Surabaya: Media Sahabat Cendekia

Mirdanda, A. (2018). Motivasi Berprestasi \& Disiplin Peserta Didik Serta Hubungannya Dengan Hasil Belajar. Pontianak: Yudha English Gallery

Muniroh, A. (2015). Academic Angagement. Yogyakarta: LKiS Pelangi Aksara

Simatupang, H \& Purnama, D., (2019). Handbook Best Practice Strategi Belajar Mengajar. Surabaya: Pustaka Media Guru

Sinar. (2018). Metode Active Learning. Yogyakarta. Deepublish

Susanto, H. (2014). Seputar Pembelajaran Sejarah: Isu, Gagasan dan Strategi dalam Pembelajaran. Yogyakarta: Aswaja Pressindo.

Susanto, H \& Akmal, H. (2019). Media Pembelajaran Sejarah Era Teknologi Informasi (Konsep Dasar, Prinsip Aplikatif, dan Perancangannya). Banjarmasin: Program Studi Pendidikan Sejarah Fakultas Keguruan dan Ilmu Pendidikan Universitas Lambung Mangkurat

Syahputra, E. (2020). Snowball Throwing Tingkatkan Minat Dan Hasil Belajar. Sukabumi: Haura Publishing

\section{B. Jurnal}

Khotimah, K. \& Wardani, D,K. (2020). PENGEMBANGAN METODE PEMBELAJARAN CIRCOS UNTUK MENINGKATKAN PRESTASI BELAJAR SISWA. Jurnal Of Education And Management Studies Vol. 3, No. 2, April 2020 Hal. 27-36.

Nafiah, Y,N. dan Suyanto, W. (2014). PENERAPAN MODEL PROBLEMBASED LEARNING UNTUK MENINGKATKAN KETERAMPILAN BERPIKIR KRITIS DAN HASIL BELAJAR SISWA. Jurnal Pendidikan Vokasi, Vol 4, Nomor 1, Februari 2014. 
Prawitasari, Melisa (2015). METODE PEMBELAJARAN HYPNOTEACHING MELALUI MIND MAPPING DALAM PEMBELAJARAN SEJARAH (STUDI PADA SISWA KELAS XI IPS SMA PGRI 6 BANJARMASIN). Seminar Nasional.

Rerung, N. dkk. (2017). PENERAPAN MODEL PEMBELAJARAN PROBLEM BASED LEARNING (PBL) UNTUK MENINGKATKAN HASIL BELAJAR PESERTA DIDIK SMA PADA MATERI USAHA DAN ENERGI. Jurnal Ilmiah Pendidikan Fisika al-BiRuNi, 06 (01) (2017) 4755 .

Setyorini, dkk. (2011). PENERAPAN MODEL PROBLEM BASED LEARNING UNTUK MENINGKATKAN KEMAMPUAN BERPIKIR KRITIS SISWA SMP. Jurnal Pendidikan Fisika Indonesia, 7(2011) 52-56.

Susanto, H. (2015). MENGHADIRKAN KELAS KONTRUKTIVIS DALAM MELATIH KEMAMPUAN BERPIKIR HISTORIS MELALUI MODEL LATIHAN PENELITIAN.

Susanto, H., \& Akmal, H. (2018). EFEKTIVITAS PENGGUNAAN APLIKASI PEMBELAJARAN BERBASIS MOBILE SMARTPHONE SEBAGAI MEDIA PENGENALAN SEJARAH LOKAL MASA REVOLUSI FISIK DI KALIMANTAN SELATAN PADA SISWA SEKOLAH MENENGAH ATAS. HISTORIA: Jurnal Program Studi Pendidikan Sejarah, 6(2), 197-206. 